\title{
Yield reduction of spring wheat in relation to disease development caused by Septoria nodorum
}

\author{
REIJO KARJALAINEN and SINIKKA KARJALAINEN \\ Department of Plant Pathology, University of Helsinki, \\ SF-00710 Helsinki, Finland
}

\begin{abstract}
Effects of Septoria nodorum on the grain yields and yield components of three spring wheat cultivars were studied in Finland using artificial field inoculation over three years.

At low infection level, in 1986, grain yield was reduced in all cultivars by $2-10 \%$, but statistically insignificantly. In 1984 severe infection reduced the grain yields of cultivars Kadett and Tähti by $27 \%$ and $32 \%$, respectively, while in 1985 the yield of Tähti was reduced by $16 \%$ and that of Kadett by $18 \%$.

Grain weights were reduced under low disease stress by $3-5 \%$, while under severe disease stress the reductions were $7-20 \%$.

Disease strongly reduced the green-leaf area duration compared with fungicide-treated plots. Examination of single tillers showed that all yield components were significantly reduced. The disease amount on second leaves correlated best with grain weight loss.

Implications of these results for controlling the damage caused by $S$. nodorum in spring wheat are discussed.
\end{abstract}

Index words: Septoria nodorum, yield loss, spring wheat

\section{Introduction}

Septoria nodorum Berk., the cause of glume blotch disease of wheat, has become one of the most important cereal diseases in northern Europe and many other parts of the world in recent decades (EYAL 1981, KING et al. 1983 a). Increasing Septoria severity is likely to be related to changes in cultivars and husbandry practices, which have provided new opportunities for disease outbreaks in many areas. Crop losses caused by $S$. nodorum vary from $5 \%$ to $70 \%$ (reviewed by KING et al. 1983 a, KarJalainen 1985), and in Finland previous studies (KARJALAINEN et al. 1983, KARJALAINEN 1985) have shown yield losses of $10-35 \%$ depending on the year and the cultivar. Yield reduction might be related to the reduction in photosynthetic rate as well as to the reduction in overall photosynthesis, which is mainly due to disease-induced speeding up of senescence (SCHAREN and KRUPINSKY 1969, 
Spierz 1973, Karjalainen and SalovaAra 1988). .

Septoria has been a major wheat pathogen in Finland for a long time (MÄKELÄ 1973), and our climate together with field characteristics favour its epidemic development. In most years summers are cool and there are frequent rains. In addition, wheat fields are often small and surrounded by lakes or forests which provide the humidity in wheat canopy necessary for disease development. In recent years farmers in southern Finland, in particular, have increasingly started to use growth regulators and extra nitrogen as well as in some cases zero tillage, which all may have a disease speeding effect. However, these farmers have found it necessary to regularly use fungicides to control leaf diseases. Septoria epidemics can be sporadic, and careful disease monitoring may allow to forecast the risk of Septoria occurrence and at the same time help to avoid unnecessary treatments while providing information on the accurate spray timing for fungicide application (ROYLE et al. 1986).

The purpose of this study was to provide more information on how Septoria affects some yield characteristics of spring wheat cultivars under severe and mild epidemic conditions.

\section{Materials and methods}

Yield reduction in spring wheat caused by Septoria nodorum was studied in the years 1984-1986. Three cultivars, susceptible Tähti and Hankkija's Tapio, and moderately resistant Kadett, were used in field tests carried out at the University Farm of Viikki of the University of Helsinki. Experiments were carried out in a randomized block design with $6-8$ replications, half of which were inoculated with $S$. nodorum. All inoculated plots were surrounded by guard plots to prevent inoculum spread into control plots. Standard fertilization and herbicide treatments were used. In 1986, 0.5 1/ha of Tilt was applied on some plots of Tähti and Tapio just before flag leaf emergence in order to evaluate the effect of a fungicide to control Septoria.

Inoculation was done by spraying $S$. nodorum spore suspension onto test plots. Mixtures of three fungal isolates collected from southern Finland were used. The fungus was cultured on oatmeal agar in petri dishes under NUV light for 7-10 days. The dishes were then flooded with sterile water and spores were released by gently rubbing the agar surface with a spatula. Spore suspensions of about $10^{6}$ spores $/ \mathrm{ml}$ with some 'Tween 20' were used for inoculation.

In 1984 and 1985 test plots were inoculated twice, at the third leaf stage and one week after that. In 1986, three inoculations were done, starting at the third leaf stage. Inoculations were done late in the evening, using $50 \mathrm{ml}$ of spore suspension per plot.

Disease development was monitored by counting and labelling 60 plants per plot and estimating the percentage of diseased leaf area on three upper leaves. Green-leaf area duration was monitored by visually estimating non-green leaf area, which was more accurate to estimate than green-leaf area.

Before harvest, the 60 labelled tillers per plot were collected and their yield components wẹre analyzed. Grain yields and thousand grain weights were analyzed from larger data.

Single-tiller analysis was also carried out by labelling 60 tillers in a large commercial field of cultivar Tapio. Before harvest the labelled tillers were taken for yield component analysis.

Correlation, regression, and variance analyses were computed from yield data.

\section{Results}

\section{Disease development}

Patterns of disease development of Septoria nodorum on three spring wheat cultivars are presented from two years, 1984 and 1986, when conditions for infection varied greatly. In 1984 the weather was very suitable for rapid disease development because of frequent 
rains, and even the first leaves were rapidly covered by diseased lesions. In this year (Fig. 1) the late but susceptible cultivar Tähti was slowly infected at the beginning of the growing period, but after ear emergence infection advanced quickly. A similar pattern of disease development was noticed for all three cultivars so that Kadett was consistently the most resistant and Tähti the most susceptible one, while Tapio was intermediate.

In 1986 the weather was unsuitable for rapid disease development because there was a long rainless period in the growing season. Disease development on two upper leaves was monitored on Tähti and Kadett. In general, infection started slowly despite several inoculations to induce disease build-up so that only about $30 \%$ of the first leaves of susceptible Tähti was destroyed at the end of July, while the first leaves were totally destroyed at that time in 1984. In 1986, the first leaves of Kadett were only slightly infected (Fig. 2), and Kadett was again clearly more resistant than Tähti throughout the growing period.

A separate experiment was also carried out in 1986 to test the effectiveness of fungicide treatments (Tilt) to reduce disease development. Treatments before flag leaf emergence efficiently prevented disease build-up on both Tähti and Tapio (Fig. 3).

Development of leaf area $\left(\mathrm{cm}^{2}\right)$ on cultivars Kadett and Tähti was monitored over a threeweak period under severe disease stress in 1984. At the beginning, leaf area was larger on susceptible and larger-leafed Tähti than on Kadett, but the leaf area of Tähti rapidly reduced toward the end of the period compared with that of resistant Kadett (Fig. 4).

In 1986, the effect of disease on reducing green-leaf area was monitored by visually estimating the non-green leaf area on flag leaves. Reduction in green-leaf area appeared to follow a similar pattern on both Kadett and Tähti (Fig. 5), and more resistant Kadett appeared to prolong upper leaf green area duration slightly longer than susceptible Tähti. However, at the end of the period there was

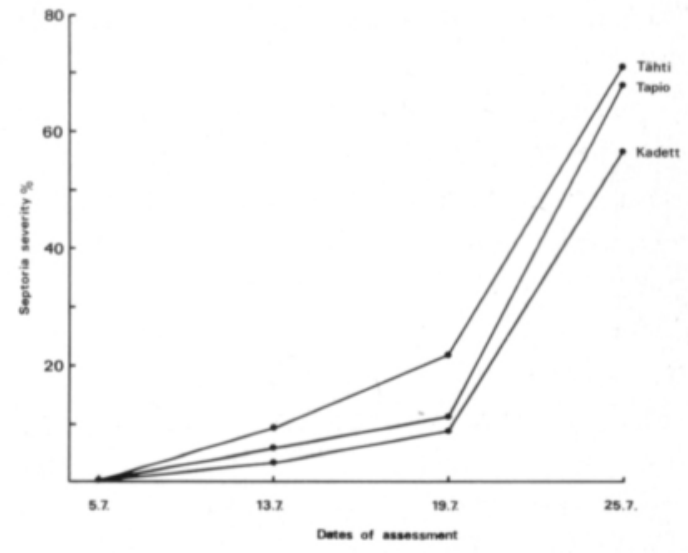

Fig. 1. Disease progress of Septoria nodorum on the flag leaves of spring wheat cultivars Tähti, Tapio, and Kadett in 1984.

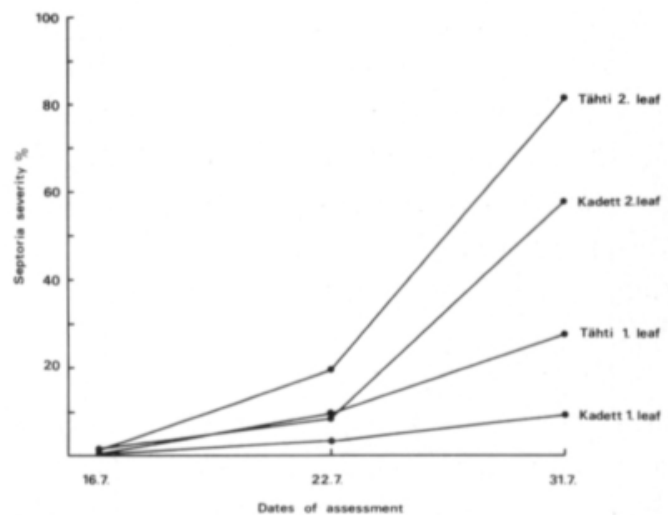

Fig. 2. Disease progress of $S$. nodorum on the flag and second leaves of spring wheat cultivars Tähti and Kadett in 1985.

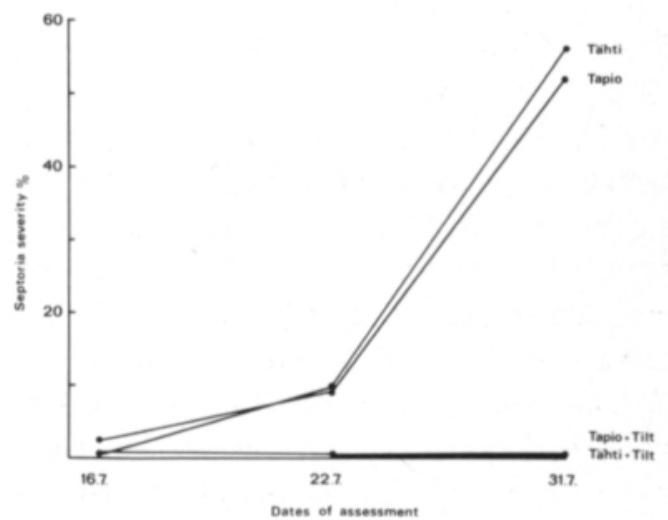

Fig. 3. Effects of Tilt-treatment on disease progress of $S$. nodorum on the second leaves of spring wheat cultivars Tapio and Tähti. 


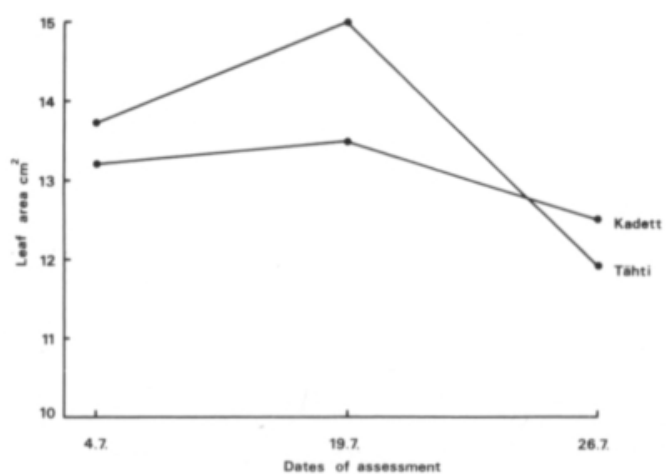

Fig. 4. Development of flag leaf area under disease stress conditions in 1984 on the cultivars Tähti and Kadett.

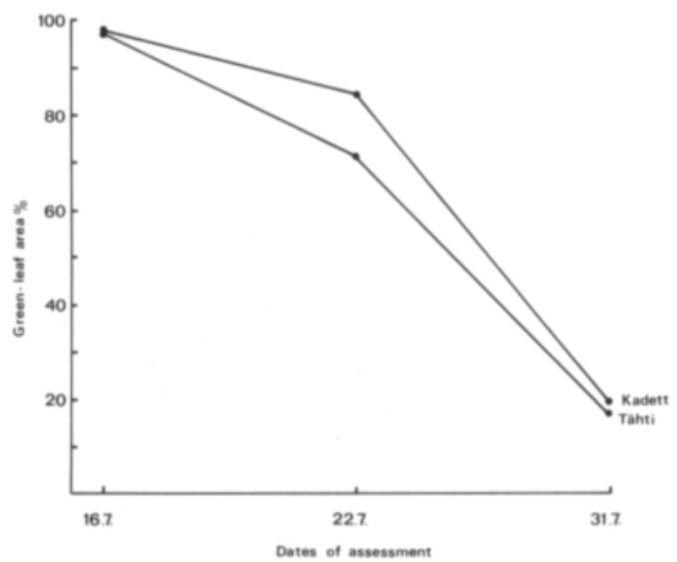

Fig. 5. Reduction in green-leaf area of the flag leaves of cultivars Tăhti and Kadett under disease stress in 1986.

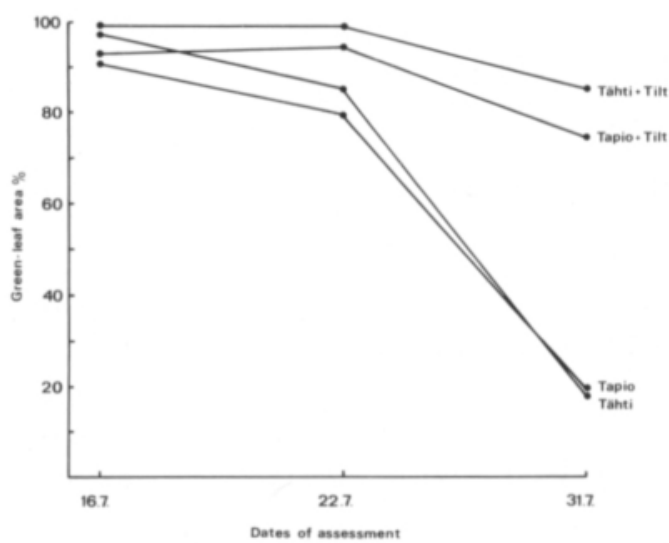

Fig. 6. Effects of Tilt-treatment on the green-leaf area development of the flag leaves of cultivars Tähti and Tapio in 1986. hardly any difference between these two cultivars. Fungicide treatments (Tilt) effectively prolonged green-leaf area duration of both Tähti and Tapio (Fig. 6), suggesting that a fungicide treatment may help preserve more green-leaf area for photosynthesis, which in turn produces an increased supply of assimilates to be translocated into the grain compared to untreated control.

\section{Effects of disease on grain yield and yield components}

In 1984 and 1985 the weather was suitable for disease development, and the yield data

Table 1. Effect of Septoria infection on grain yield and grain weight of spring wheat cultivar Tähti in 1984-1985.

\begin{tabular}{lrrrr}
\hline & $\begin{array}{c}\text { Grain } \\
\text { yield } \\
\text { kg/ha }\end{array}$ & Ratio & $\begin{array}{c}1000- \\
\text { grain } \\
\text { weight, } \\
\text { g }\end{array}$ & Ratio \\
& & \multicolumn{3}{c}{} \\
\hline 1984 & & & & \\
Control & 4617 & 100 & 39.3 & 100 \\
Septoria-inoculated & 3156 & 68 & 31.6 & 80 \\
Significance & $* * *$ & & $*$ & \\
L.S.D.5 & 623 & & 1.6 & \\
1985 & & & & \\
Control & 2540 & 100 & 33.3 & 100 \\
Septoria-inoculated & 2140 & 84 & 28.8 & 86 \\
Significance & $*$ & & $*$ & \\
L.S.D.5 $\%$ & 290 & & 3.1 & \\
\hline
\end{tabular}

Table 2. Effect of Septoria infection on grain yield and grain weight of spring wheat cultivar Kadett in 19841985.

\begin{tabular}{|c|c|c|}
\hline $\begin{array}{c}\text { Grain } \\
\text { yield } \\
\mathrm{kg} / \mathrm{ha}\end{array}$ & Ratio & $\begin{array}{c}1000- \\
\text { grain } \\
\text { weight, } \\
\text { g }\end{array}$ \\
\hline
\end{tabular}

\begin{tabular}{lrrrr}
1984 & & & & \\
Control & 6287 & 100 & 41.5 & 100 \\
Septoria-inoculated & 4603 & 73 & 33.1 & 80 \\
Significance & $* *$ & & $*$ & \\
L.S.D.5 & 850 & & 1.2 & \\
1985 & & & & \\
Control & 3305 & 100 & 38.0 & 100 \\
Septoria-inoculated & 2723 & 82 & 35.5 & 93 \\
Significance & $*$ & & N.S. & \\
L.S.D.5 & 450 & & 2.9 & \\
\hline
\end{tabular}

N.S. = non-significant 
show (Tables $1 \& 2$ ) that $S$. nodorum is capable of causing significant yield reductions to wheat crops. In 1984, the disease reduced the grain yields of susceptible Tähti and more resistant Kadett by $32 \%$ and $27 \%$, respectively (Table 1). The grain weights of both cultivars were significantly reduced, by $20 \%$. In 1985 the yields of all test cultivars were generally very low, and the yield of Tähti was reduced by $16 \%$ and that of Kadett by $18 \%$. The grain weight of Tähti was again significantly reduced (Table 2 ).

In 1986 there was a long dry period during the experiment, and $S$. nodorum was unable to grow rapidly into the upper parts of the wheat canopy. Thus grain yields were only slightly reduced. Disease-induced yield reductions for all three cultivars, Tähti, Kadett, and Tapio, were statistically insignificant (Table 3), although the yield of Tähti was reduced by over $400 \mathrm{~kg} / \mathrm{ha}$. The yields of Kadett and Tapio were less affected by the disease. Table 4 summarizes the yield data from Tähti and Kadett over three years showing that only the yield of more susceptible Tähti was significantly affected by the disease, while a more stable trait, grain weight, indicates significant reductions for both cultivars.

Yield component data were also obtained from a single-tiller assessment experiment from cultivar Tähti. Results indicated (Table 5) that all yield components were significantly reduced by the infection. As results from previous studies (e.g. KARJALAINEN 1985) had suggested that grain weight is a stable component of grain yield, which characterizes yield reduction in a reliable way, single-tiller assessments were carried out on a commercial plot of Tapio in order to assess the amount of disease on two upper leaves and to find out which leaf, leaf 1 or leaf 2 , correlates best with grain weight reduction. Fig. 7 indicates that in general the amount of disease on either leaf correlates well with grain weight reduction, but the second leaf appears to be an even better indicator of grain weight loss than the first one.
Table 3. Effect of Septoria infection on grain yields and grain weights of spring wheat cultivars Tăhti, Kadett, and Tapio in 1986.

\begin{tabular}{|c|c|c|c|c|}
\hline Cultivars & $\begin{array}{c}\text { Grain } \\
\text { yield } \\
\mathrm{kg} / \mathrm{ha}\end{array}$ & Ratio & $\begin{array}{c}1000- \\
\text { grain } \\
\text { weight, } \\
\text { g }\end{array}$ & Ratio \\
\hline \multicolumn{5}{|l|}{ Tähti } \\
\hline Control & 4280 & 100 & 40.9 & 100 \\
\hline Septoria-inoculated & 3847 & 90 & 39.3 & 96 \\
\hline Significance & N.S. & & N.S. & \\
\hline L.S.D. $5 \%$ & 637 & & 4.4 & \\
\hline \multicolumn{5}{|l|}{ Kadett } \\
\hline Control & 5127 & 100 & 44.9 & 100 \\
\hline Septoria-inoculated & 5019 & 98 & 42.6 & 95 \\
\hline Significance & N.S. & & N.S. & \\
\hline L.S.D.5\% & 1385 & & 5.6 & \\
\hline \multicolumn{5}{|l|}{ Tapio } \\
\hline Control & 4986 & 100 & 43.7 & 100 \\
\hline Septoria-inoculated & 4710 & 94 & 42.3 & 97 \\
\hline Significance & N.S. & & N.S. & \\
\hline L.S.D. $5 \%$ & 491 & & 9.3 & \\
\hline
\end{tabular}

N.S. = non-significant

Table 4. Combined data over three years of the effects of Septoria on grain yields and 1000-grain weights of cultivars Tăhti and Kadett in 1984-1986.

\begin{tabular}{lrrrr}
\hline Cultivars & $\begin{array}{c}\text { Grain } \\
\text { yield } \\
\mathrm{kg} / \mathrm{ha}\end{array}$ & Ratio & $\begin{array}{c}1000- \\
\text { grain } \\
\text { weight, } \\
\text { g }\end{array}$ & Ratio \\
\hline Tahti & & & & \\
Control & 3999 & 100 & 38.7 & 100 \\
Septoria-inoculated & 3277 & 82 & 33.8 & 87 \\
Significance & $*$ & & $* * *$ & \\
L.S.D.5 & 545 & & 2.5 & \\
Kadett & & & & \\
Control & 4775 & 100 & 41.4 & 100 \\
Septoria-inoculated & 4117 & 86 & 37.7 & 91 \\
Significance & N.S. & & $*$ & \\
L.S.D.5 \% & 1091 & & 3.6 & \\
\hline
\end{tabular}

N.S. = non-significant

Table 5. Effect of $S$. nodorum on yield components of spring wheat cultivar Tähti in 1986.

\begin{tabular}{lccc}
\hline & $\begin{array}{c}\text { Number } \\
\text { of grains } \\
\text { per ear }\end{array}$ & $\begin{array}{c}\text { Ear } \\
\text { weight } \\
\mathrm{g}\end{array}$ & $\begin{array}{c}\text { 1000-grain } \\
\text { weight, } \\
\mathrm{g}\end{array}$ \\
\hline Control & 22.4 & 0.84 & 37.4 \\
Septoria-inoculated & 18.7 & 0.62 & 32.6 \\
Significance & $* * *$ & $* * *$ & $* * *$ \\
L.S.D.5 & 1.7 & 0.08 & 1.3 \\
\hline
\end{tabular}




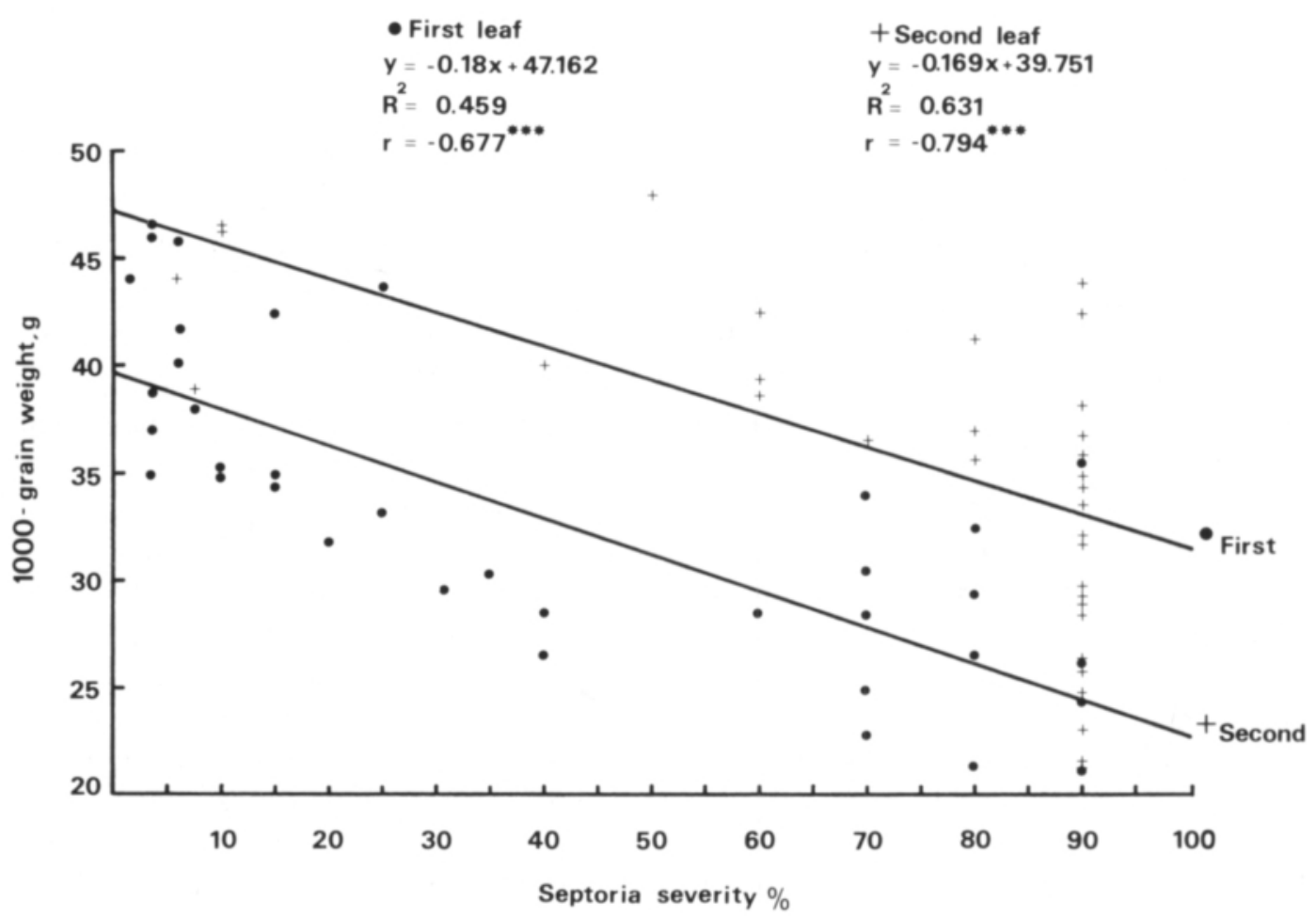

Fig. 7. Correlation between $S$. nodorum severity and grain weight on the first and second leaves of cultivar Tapio.

\section{Discussion}

Our results suggest that under humid conditions favourable for disease development, $S$. nodorum can cause yield losses as high as $20-32 \%$. In the past ten years there have been several rainy summers (e.g. 1981, 1984, $1985,1987)$ and severe occurrences of S. nodorum.

There are two types of epidemic development of $S$. nodorum, sudden outbreaks and gradual epidemics (Royle et al. 1986). In a sudden outbreak disease lesions appear simultaneously on all upper leaves, usually early in crop growth. These outbreaks are related with a single heavy rain that moves the basal inoculum $50-60 \mathrm{~cm}$ upwards within the crop. Inoculum transport also depends on the size of the raindrops because large drops produce large splash droplets (BRENNAN et al. 1985).

In gradual epidemics the disease arises on successive leaf layers as they appear during the sustained weather period suitable for inocu- lum travel and infection. In Finland, gradual epidemics are probably more common than sudden outbreaks, and infection in the field often appears to follow this pattern.

A severe Septoria infection seems to have complex reasons. A previous rainy season probably affects next year's epidemic conditions by providing abundant infected plant debris on the soil because in Finland the fall is often wet, which makes ploughing difficult. If the first part of the growing season is cool and wet, inoculum can be transported to new wheat crops early, and if there are several rainy days between mid-June and late July, the disease can gradually progress from lower to upper canopy.

Our results in 1986 showed that even under unsuitable dry conditions $S$. nodorum can reduce wheat yield by $5-10 \%$. Even in a rainless period, Septoria may survive and develop in the canopy because in late season dew provides humidity for several hours. However, practical experience suggests that hot and 
dry weather for several weeks (e.g. in 1983 and 1986) effectively retards Septoria development.

In this paper we have shown that Septoriainfection speeds up senescense and shortens green-leaf area duration. This in turn reduces overall photosynthesis and decreases the supply of assimilates that can be translocated to the grain. It was thus logical that the grain weight was strongly affected in this experiment. Our results also showed that fungicide treatment effectively reduced disease development and particularly prolonged flag leaf period thus also lengthening grain-filling time. This is in accordance with earlier data (SPIERZ 1973) indicating that a fungicide treatment given at the right time can effectively reduce disease and increase grain yield. In our experiments fungicide treatments increased the grain yields of spring wheat by $5-30 \%$ compared with untreated controls. Although infection seems to reduce green-leaf area and overall photosynthesis so drastically, it may have only a small effect on the pattern of assimilate distribution (WAFFORD and WhITBREAD 1976).

In our experiments all yield components were strongly affected by infection as revealed by the single-tiller experiment, which is in line with earlier data (JoNES and RowLING 1976, WAFFORD and WhitBREAD 1978, KARJALAINEN et al. 1983). In general, early infection appears to reduce yield less than a late one (JONES and Rowling 1976, Verreet et al. 1987), and single-ear yields in particular are strongly affected by late infection. Field data (BRöN. Nimann 1968, Spierz 1973, Nelson et al. 1976, SCOTT and BENEDIKZ 1977, W WFFORD and Whitbread 1978, Karjalainen et al. 1983, VERREET et al. 1987) show quite consistently that wheat is sensitive to $S$. nodorum at a later stage of development, and greatest losses occur after late infection. Sometimes losses caused by early infection are compensated by other yield components if the infection is weak or moderate (JONES and RowLING 1976, WAFFORD and Whitbread 1978), but compensation is probably not effective enough to prevent yield losses after severe infection. In Finland, wheat is most often infected in late season, and as the amount of rain increases towards the end of the growing season, Septoria infection frequently speeds up at the same time. Yield losses in Finnish wheat crops thus seem to be mainly due to late Septoria attacks.

These data indicate yield losses of $20-$ $30 \%$ under severe and 5-10\% under mild disease conditions. Previously we reported a $10 \%$ reduction in one cultivar and one year (KARJALAINEN et al. 1983). In the rainy years of 1981, 1984, 1985, and 1987, there was often as much Septoria in many farmers' fields as in our experimental fields. However, disease distribution even in a single field varies. Estimates of national losses caused by $S$. nodorum in Finland are not available, but annual yield losses of up to $8 \%$ have been recorded in Great Britain. KING et al. (1983 b) have provided a linear regression equation between disease severity and yield loss. It indicated a yield loss of $1.011 \%$ for each $1 \%$ increment in severity on the flag leaf and a loss of $0.551 \%$ for each $1 \%$ increment on the second leaf. Our single-tiller analysis done in a commercial field of cultivar Tapio suggested that the amount of disease on the second leaf correlates best with grain yield loss. Under northern growing conditions the second leaf may be a better crop loss estimate than the flag leaf because in the field it is often more reliable to estimate the amount of disease (without inoculation) on the second than on the flag leaf.

The use of fungicides to control wheat diseases has increased in the past few years. In some areas in southern Finland winter wheat is sprayed first at the stem extension phase mainly to control mildew and again later to control Septoria. In Finland Septoria seems to cause greatest crop losses rather late in crop growth, and one spraying with optimal timing would probably be sufficient. In this experiment, one application immediately after flag leaf emergence drastically reduced 
Septoria development and lengthened greenleaf area duration. Similar results have been reported by SPIERZ (1973) and OBSt (1985).

The use of simple forecasting rules (TYLDESLEY and ThOMPSON 1980, OBST 1985) and information of the previous year's weather

\section{References}

Brennan, R.M., Fitt, B.D.L., Taylor, G.S. \& Colmoun, J. 1985. Dispersal of Septoria nodorum pycnidiospores by simulated raindrops in still air. Phytopath. Z. 112: $281-290$.

Bronnimann, A. 1968. Zur Kenntnis von Septoria nodorum Berk., dem Erreger der Spelzenbräune und einer Blattdürre des Weizens. Phytopath. Z. 61: $101-146$.

EyAL, Z. 1981. Integrated control of Septoria disease of wheat. Plant Dis. 65: 763-768.

JonEs, D.G. \& Rowling, R.D.W. 1976. The reaction of two spring wheat varieties exposed to epidemics of Septoria nodorum and $S$. tritici of varying intensity and duration. J. Agric. Sci., Camb. 87: 401-406.

Karjalainen, R. 1985. Host-pathogen interaction between spring wheat and Septoria nodorum with reference to resistance breeding. J. Agric. Sci. Finl. 57: $1-66$.

- Laitinen, A. \& Juuti, T. 1983. Effects of Septoria nodorum Berk. on yield and yield components of spring wheat. J. Scient. Agric. Soc. Finl. 55: 333-344.

- \& SalovaARA, H. 1988. Effects of severe infection with Septoria nodorum on spring wheat quality. Acta Agric. Scand. 38: 183-188.

King, J.W., Cork, R.J. \& Melville, S.C. 1983 a. A review of Septoria diseases of wheat and barley. Ann. Appl. Biol. 103: 345-373.

- Jenkins, J.E.E. \& Morgan, W.A. 1983 b. The estimation of yield losses in wheat from severity of infection by Septoria species. Plant Pathol. 32: $239-249$.

Mắelä, K. 1975. Occurrence of Septoria species on cereals in Finland. J. Scient. Agric. Soc. Finl. 47: $218-244$.

Nelson, L.R., Holmes, M.R. \& Cunfer, B.M. 1976. Multiple regression accounting for wheat yield reduc- and ploughing conditions will be an important step towards the rational planning of chemical control of the Septoria disease in Finland.

Acknowledgements. Financial support from the Academy of Finland and the Ministry of Agriculture and Forestry is greatfully acknowledged.

tion by Septoria nodorum and other pathogens. Phytopathol. 66: 1375-1379.

Овsт, А. 1985. Methoden zur Prognose wichtiger Getreidekrankheiten. Bayerisches Landwirtsch. Jahrb. 62: 725-749.

Royle, D.J., Shaw, M.W. \& CoOK, R.J. 1986. Patterns of development of Septoria nodorum and $S$. tritici in some winter wheat crops in Western Europe, 1981-83. Plant Pathol. 35: 466-476.

Scharen, A.L. \& Krupinsky, J.M. 1969. Effects of Septoria nodorum infection on $\mathrm{CO}_{2}$ absorption and yield of wheat. Phytopathol. 59: 1298-1301.

Scott, P.R. \& Benedikz, P.W. 1977. Field techniques for assessing the reaction of winter wheat cultivars to Septoria nodorum. Ann. Appl. Biol. 85: 345-358.

SPIERZ, J.H.J. 1973. Effects of successive applications of maneb and benomyl on growth and yield of five wheat varieties of different heights. Neth. J. Agric. Sci. 21: 282-296.

Tyldesley, J.B. \& Thompson, N. 1980. Forecasting Septoria nodorum on winter wheat in England and Wales. Plant Pathol. 29: 9-20.

Verreet, J.A., Hoffmann, G.M. \& Amberger, A. 1987. Auswirkungen der Infektion durch Septoria nodorum in verschiedenen Entwicklunsstadien des Weizens auf die Produktionsleistung. Z. PflKrankh. PfISchutz 94: 283-300.

WAFFORD, J.D. \& WhitBREAD, R. 1976. Effects of leaf infections by Septoria nodorum Berk. on the translocation of ${ }^{14} \mathrm{C}$-labelled assimilates in spring wheat. Ann. Bot. 40: 83-90.

- \& Whitbread, R. 1978. Effects of inoculation with Septoria nodorum on yield components of spring wheat. Ann. Appl. Biol. 90: 323-328.

Ms received October 6, 1989 


\section{SELOSTUS}

\section{Septoria-taudin vaikutus kevätvehnän satoon}

\section{Reijo Karjalainen \\ Sinikka Karjalainen}

\section{Helsingin yliopiston kasvipatologian laitos 00710 Helsinki}

Tutkimuksessa selvitettiin Septoria-taudin vaikutusta kolmen kevătvehnälajikkeen, Tähden, Hankkijan Tapion ja Kadettin, satoon ja eräisiin satokomponentteihin vuosina 1984-1986. Kokeet tehtiin Helsingin yliopiston Viikin koetilalla saastuttamalla koeruudut laboratoriossa kasvatetusta Septoria nodorum -sienestä tehdyllä itiöseoksella. Osa Tăhti- ja Tapio-ruuduista käsiteltiin Tiltillă juuri ennen lippulehden puhkeamista.

Taudin kehitystă kasvustossa seurattiin arvioimalla tietyin vălein tautilaikkujen mäără kahdella ylimmällă lehdellă. Samanaikaisesti mäăritettiin ylälehtien kuihtumisaste. Sadonkorjuun jälkeen laskettiin jyvăsato ja 1000-jyvăn paino ja mäăritettiin satokomponentit yksilöpuiduista Tapion ja Tăhden tăhkistă.

Sảä vaikuttaa ratkaisevasti Septoria-taudin leviämiseen. Vuodet 1984 ja 1985 olivat sateisia ja viileitä, jolloin tauti levisi nopeasti kasvuston alaosista ylälehtiin ja tähkiin asti. Vuosi 1986 oli kuuma ja kuiva, taudille epăsuotuisa. Kaikissa kokeissa Septoriaa vastaan kestävin oli Kadett ja alttein Tähti, Tapio sijoittui näiden văliin.

Vuonna 1984 Kadettin jyvăsato oli $27 \%$ ja Tăhden $32 \%$ pienempi kuin saastuttamattoman verranteen. Kummankin 1000-jyvän paino aleni $20 \%$. Vuonna 1985 sadot olivat yleensả alhaisia, ja Tähden sadonalennus oli
$16 \%$ ja Kadettin $18 \%$. 1000-jyvăn painot alenivat vastaavasti $14 \%$ ja $7 \%$. Vuonna 1986 Septoriaa oli niin vähăn, ettă sadonalennukset olivat tilastollisesti merkityksettömiă.

Tauti alensi huomattavasti kaikkia Tăhden satokomponentteja. Tapio-viljelykseltä otettu näyte osoitti, ettả taudin mäără sekä lippulehdellă ettă erityisesti toiseksi ylimmällä lehdellă korreloi selvăsti 1000 -jyvän painon alenemiseen, mikă satokomponentti yleensä kuvaa luotettavasti Septoria-taudin vaikutusta.

Vihreän lehtialan seuranta osoitti, että Septoria-infektio nopeuttaa kasvin kuihtumista, jolloin yhteyttảvă lehtiala pienenee ja yhteyttămisaika lyhenee, minkä seurauksena jyvăkoko pienenee. Tiltin vaikutus lieneekin perustunut osin siihen, että se paitsi văhensi taudin kehitystä myös vaikutti lehtialan săilymiseen vihreănă pidempaaan. Tulokset viittaavat siihen, ettă Suomessa torjuntakăsittely on paikallaan sateisina kesinä. Torjunnan paras ajoitus näyttäă olevan lippulehden puhkeamisen ja tăhkälletulon vălillă, jolloin kăsittely estảả tehokkaasti patogeenipopulaation etenemisen kasvustossa ja lehtien ennenaikaisen kuihtumisen. Viileänä kasvukautena torjunta pidentäă myöhäisten lajikkeiden kasvuaikaa entisestaăn. 